\title{
Synthesis, characterization and computational studies of 2-cyano-6-methoxybenzothiazole as a firefly-luciferin precursor
}

https://doi.org/10.1515/hc-2018-0047

Received March 21, 2018; accepted July 10, 2018; previously published online August 27, 2018

Abstract: A novel approach to the synthesis of 2-cyano6-methoxybenzothiazole via the Cu-catalyzed cyanation of 2-iodo-6-methoxybenzothiazole was developed. $\mathrm{K}_{4}\left[\mathrm{Fe}(\mathrm{CN})_{6}\right]$ was used as a source of cyanide, and a $\mathrm{Cu} / \mathrm{N}, \mathrm{N}, \mathrm{N}^{\prime}, \mathrm{N}^{\prime}$-tetramethylethylenediamine (TMEDA) system was utilized as a catalyst. This approach is scalable and can be practiced with operational benign. The most stable conformation of 2-cyano-6-methoxybenzothiazole was delineated using the density functional theory (DFT)/ B3LYP method with 6-311++G(d, p) basis set.

Keywords: 2-cyano-6-methoxybenzothiazole; 2-iodo6-methoxyenzothiazole; Cu catalyst; cyanation; DFT; firefly luciferin; $\mathrm{K}_{4}\left[\mathrm{Fe}(\mathrm{CN})_{6}\right]$.

\section{Introduction}

Firefly luciferin is a common substrate in biological imaging [1] that originates from some insects [2]. It is widely applied in life sciences [3-5]. The chemical preparation of firefly luciferin has been described previously [6-9]. In particular, 2-cyano-6-methoxybenzothiazole has been converted to 2-cyano-6-hydroxybenzothiazole followed by the reaction with cysteine [6] (Scheme 1). Typical routes to 2-cyano-6-methoxybenzothiazole include the classical Rosenmund-von Braun [10] and Sandmeyer [11] reactions. These methods proceed with low atom economy and require toxic reagents such as KCN [12], NaCN [13], $\mathrm{Zn}(\mathrm{CN})_{2}$ or TMSCN [14] that are also difficult to handle in a large-scale synthesis $[15,16]$.

The Cu-catalyzed cyanation of aryl halides to benzonitrile derivatives has been reported [13]. Various copper catalyst systems with bidentate ligands [17-23] have been

*Corresponding author: Saeid Amani, Department of Chemistry, Faculty of Science, Arak University, P.O. Box: 38156-88349, Arak, Iran, e-mail: s-amani@araku.ac.ir, amani1331@yahoo.com

Ghasem Shahmoradi: Department of Chemistry, Faculty of Science, Arak University, P.O. Box: 38156-88349, Arak, Iran developed. In 2004, Beller and co-workers introduced $\mathrm{K}_{4}\left[\mathrm{Fe}(\mathrm{CN})_{6}\right]$ as a low-cost and eco-friendly source of cyanide [19]. Due to its strong CN bond, the catalyst deactivation was prevented through a slow release of cyanide ion [24]. Herein, a Cu-catalyzed cyanation of 2-iodo-6-methoxybenzothiazole for the synthesis of 2-cyano-6-methoxybenzothiazole was introduced. $\mathrm{K}_{4}\left[\mathrm{Fe}(\mathrm{CN})_{6}\right]$ was applied as a source of cyanide, and $\mathrm{CuI}$ in the presence of $\mathrm{N}, \mathrm{N} \mathrm{N} \mathrm{N}^{\prime}, \mathrm{N}^{\prime}$ tetramethylethylenediamine (TMEDA) [25] was used as part of the catalyst system. Density functional theory (DFT) calculations were made with the structural parameters calculated using the B3LYP/6-311++G(d, p) method [26-29].

\section{Results and discussion}

2-Amino-6-methoxybenzothiazole as a starting material was synthesized from $p$-anisidine as shown in Scheme 2 [30] and subsequently converted into 2-iodo-6-methoxybenzothiazole using a simple and efficient one-pot sequential diazotization-iodination method.

Reagents and conditions: (a) $-\mathrm{CH}_{3} \mathrm{COOH}, \mathrm{Br}_{2}, \mathrm{KSCN}$, $20 \mathrm{~h}$, temperature $<35^{\circ} \mathrm{C}$, yield $85 \%$; (b) $-\mathrm{H}_{2} \mathrm{SO}_{4}, \mathrm{NaNO}_{2}$, $\mathrm{KI}, 0^{\circ} \mathrm{C}, 30 \mathrm{~min}$, yield $80 \%$.

The one-pot cyanation of 2-iodo-6-methoxybenzothiazole to 2-cyano-6-methoxybenzothiazole was achieved using $0.25 \mathrm{mmol}$ of $\mathrm{K}_{4}\left[\mathrm{Fe}(\mathrm{CN})_{6}\right], 0.25 \mathrm{mmol}$ of $\mathrm{CuI}$ and $3 \mathrm{mmol}$ of TMEDA in acetonitrile at $160^{\circ} \mathrm{C}$ (Scheme 3). In addition, $1 \mathrm{mmol}$ of mystril trimethyl bromide (MTMAB) was used as a phase transfer agent. The presence of a phase-transfer catalyst is essential for a successful cyanation reaction. Under these conditions, 2-cyano-6-methoxybenzothiazole was produced in a $90 \%$ yield. In the presence of $0.18 \mathrm{mmol}$ of $\mathrm{K}_{4}\left[\mathrm{Fe}(\mathrm{CN})_{6}\right]$, the cyanation still proceeded in a $90 \%$ yield, indicating that all six cyanide ions in the molecule are utilized in the reaction. On the other hand, increasing the amount of $\mathrm{K}_{4}\left[\mathrm{Fe}(\mathrm{CN})_{6}\right]$ to more than $0.25 \mathrm{mmol}$ resulted in a moderate yield of $60 \%$, presumably due to the catalyst deactivation. In addition, a decrease in the $\mathrm{CuI}$ loading to $0.1 \mathrm{mmol}$ from $0.25 \mathrm{mmol}$, resulted in a poor yield of $40 \%$, even after an increase of the reaction time to $40 \mathrm{~h}$. 
<smiles>N#Cc1nc2ccc(O)cc2s1</smiles>

Scheme 1 Synthesis of firefly luciferin.<smiles>COc1ccc(N)cc1</smiles>

Scheme 2 Synthesis of 2-iodo-6-methoxybenzothiazole from $p$-anisidine.

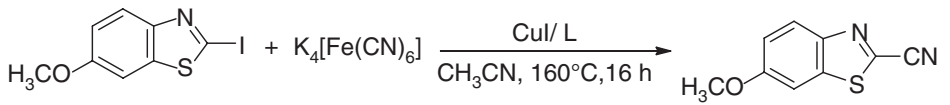

Scheme 3 Cyanation reaction of 2-iodo-6-methoxybenzothiazole.

The optimized geometric structures of 2-cyano6-methoxyoxybenzothiazole were calculated using the B3LYP 6-311++G(d, p) method. This molecule has $\mathrm{C} 1$ full point group and 51 fundamental modes of vibrations. It exists in two stable conformers, I and II. Conformer III is the transition state structure (Figure 1). Conformer I with the dihedral angle (C7-C6-O15-C16) of $1.4^{\circ}$ is $0.17 \mathrm{kcal} / \mathrm{mol}$ more stable than conformer II and $2.02 \mathrm{kcal} / \mathrm{mol}$ more stable than conformer III. The dihedral angle (C7-C6-O15C16) of the second stable structure is $179.98^{\circ}$.

\section{Conclusions}

2-Cyano-6-methoxybenzothiazole, a synthetic intermediate of firefly luciferin, was prepared by a high-yield Cu-catalyzed cyanation of 2-iodo-6-methoxybenzothiazole. $\mathrm{K}_{4}\left[\mathrm{Fe}(\mathrm{CN})_{6}\right]$ was applied as an eco-friendly cyanide source. The cyanation reaction was performed efficiently by applying the catalytic system of CuI/TMEDA that is non-toxic and environmentally friendly. The structure of 2-cyano-6-methoxybenzothiazole was characterized using computational studies.

\section{Experimental}

All chemicals and solvents were supplied by Merck (Germany) and used without purification. The Fourier transform infrared (FT-IR) spectra were recorded on an Alpha Centauri FT-IR (Bruker, Germany) spectrophotometer using $\mathrm{KBr}$ pellets. The ${ }^{1} \mathrm{H}$ NMR (300 MHz) and ${ }^{13} \mathrm{C}$ NMR $(75 \mathrm{MHz})$ spectra were determined on a Mercury-300 MHz (Bruker, Germany) instrument. The mass spectra were obtained on an Agilent 575 mass spectrometer equipped with a quadruple analyzer. 2-Amino-6-methoxybenzothiazole was synthesized according to the method described by Stuckwisch [30].

\section{Synthesis of 2-iodo-6-methoxybenzothiazole}

A solution of 2-amino-6-methoxybenzothiazole ( $1.81 \mathrm{~g}, 0.01 \mathrm{~mol})$ in water $(3 \mathrm{~mL})$ was stirred at $0^{\circ} \mathrm{C}$ and treated with acetic acid $(3 \mathrm{~mL})$ and sulfuric acid ( $6 \mathrm{M}, 4.5 \mathrm{~mL})$. The mixture was stirred for $1 \mathrm{~h}$. The resultant clear solution was treated dropwise for $15 \mathrm{~min}$ at $0^{\circ} \mathrm{C}$ with an aqueous solution ( $3 \mathrm{~mL}$ ) of $\mathrm{NaNO}_{2}(0.70 \mathrm{~g}, 0.01 \mathrm{~mol})$. After stirring for $1 \mathrm{~h}$, an aqueous solution ( $3 \mathrm{~mL}$ ) of $\mathrm{KI}$ ( $1.65 \mathrm{mg}, 0.01 \mathrm{~mol}$ ) was added slowly for $30 \mathrm{~min}$, until the evolution of nitrogen gas ceased. The product was extracted with EtOAc $(3 \times 12 \mathrm{~mL})$, and the combined organic layers were washed with a $10 \%$ aqueous solution of $\mathrm{Na}_{2} \mathrm{SO}_{4}$, dried and concentrated. The residue of 2-iodo-6-methoxybenzothiazole was
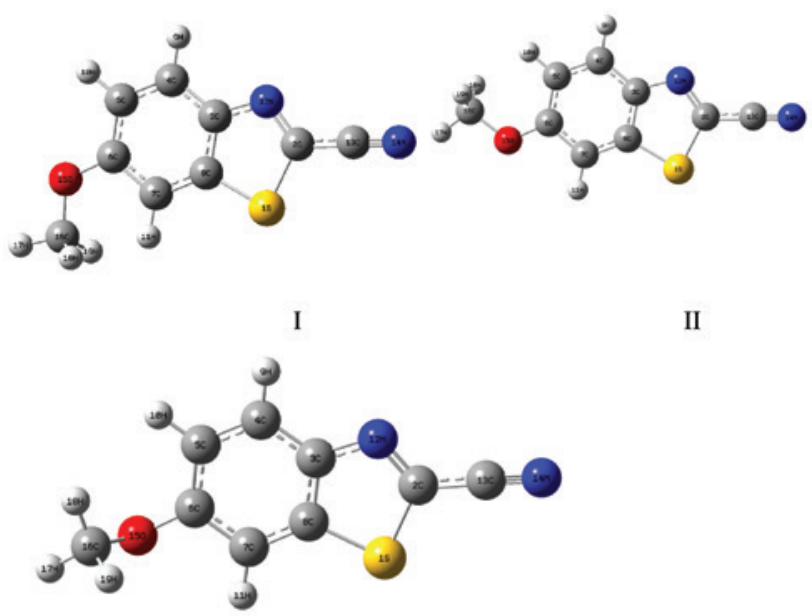

III

Figure 1 Conformers of 2-cyano-6-methoxybenzothiazole. 
crystallized from ethanol; ${ }^{1} \mathrm{H}$ NMR (300 MHz, DMSO- $\left.d_{6}\right): \delta 3.67$ (s, 3H), 6.87 (m, 1H), 7.41 (m, 1H), 7.71 (m, 1H); IR: 2932, 1651, 1239, 1208 (C-N), 1053, $875 \mathrm{~cm}^{-1}$; MS: $\mathrm{m} / z 291.0\left(\mathrm{M}^{+}\right)$. Anal. Calcd for $\mathrm{C}_{8} \mathrm{H}_{6}$ INOS: C, 33.01; H, 2.15; N: 4.87. Found: C, 32.27; H, 2.08; N, 4.81.

\section{Synthesis of 2-cyano-6-methoxybenzothiazole from 2-iodo-6-methoxybenzothiazole}

A solution of CuI $(47.6 \mathrm{mg}, 0.25 \mathrm{mmol}), \mathrm{K}_{4}\left[\mathrm{Fe}(\mathrm{CN})_{6}\right](90 \mathrm{mg}$, $0.18 \mathrm{mmol})$ and TMEDA (348 $\mathrm{mg}, 3 \mathrm{mmol})$ in dry acetonitrile $(5 \mathrm{~mL})$ was stirred for $30 \mathrm{~min}$ and then treated with MTMAB (34 mg, $1 \mathrm{mmol}$ ) and 2-iodo-6-methoxybenzothiazole (290 mg, $1 \mathrm{mmol}$ ). The mixture was stirred under argon atmosphere at room temperature for $30 \mathrm{~min}$ and then under reflux at $160^{\circ} \mathrm{C}$ for $16 \mathrm{~h}$. After cooling to room temperature, the mixture was extracted with diethyl ether $(3 \times 5 \mathrm{~mL})$. The extract was dried with anhydrous $\mathrm{MgSO}_{4}$, filtered and concentrated. The red-brown solid residue was purified by column chromatography on silica gel eluting with hexane $/ \mathrm{CH}_{2} \mathrm{Cl}_{2}, 1: 10$, to give 2-cyano-6-methoxybenzothiazole in the form of pale yellow needles; yield 90\%; mp $128-130^{\circ} \mathrm{C}$; ${ }^{1} \mathrm{H} \mathrm{NMR}\left(300 \mathrm{MHz}, \mathrm{CDCl}_{3}\right)$ : $\delta$ $3.87(\mathrm{~s}, 3 \mathrm{H}), 7.11(\mathrm{~m}, 1 \mathrm{H}), 7.23(\mathrm{~m}, 1 \mathrm{H}), 7.52(\mathrm{~m}, 1 \mathrm{H}) ;{ }^{13} \mathrm{C}$ NMR $(75 \mathrm{MHz}$, DMSO- $\left.d_{6}\right): \delta 160.6,147.3,141.3,135.6,125.6,118.6,113.1,103.5,55.6$; IR: 3030, 2932, 2240, 1651, 1280, 1207, 1034, $872 \mathrm{~cm}^{-1}$; MS: $\mathrm{m} / z 190.1$ $\left(\mathrm{M}^{+}\right)$. Anal. Calcd for $\mathrm{C}_{9} \mathrm{H}_{6} \mathrm{~N}_{2} \mathrm{OS}$ : C, 56.83; H, 3.18; N, 14.73. Found: C, 56.68; H, 3.01; N, 14.42 .

\section{References}

[1] Wood, K. V. The chemical mechanism and evolutionary development of beetle bioluminescence. Photochem. Photobiol. 1995, 62, 662-673.

[2] Ugarova, N. N.; Brovko, L. Y. Protein structure and bioluminescent spectra for firefly bioluminescence. Luminescence 2002, 17 , 321-330.

[3] Hamada, T.; Sutherland, K.; Ishikawa, M.; Miyamoto, N.; Honma, S.; Shirato, H.; Honma, K. I. In vivo imaging of clock gene expression in multiple tissues of freely moving mice. Nat. Commun. 2016, 7, 11705.

[4] Li, J.; Chen, L.; Du, L.; Li, M. Cage the firefly luciferin - a strategy for developing bioluminescent probes. Chem. Soc. Rev. 2013, 42, 662-676.

[5] Sellmyer, M. A.; Bronsart, L.; Imoto, H.; Contag, C. H.; Wandless, T. J.; Prescher, J. A. Visualizing cellular interactions with a generalized proximity reporter. Proc. Natl. Acad. Sci. USA 2013, 110, 8567-8572.

[6] White, E. H.; McCapra, F.; Field, G. F. The structure and synthesis of firefly luciferin. J. Am. Chem. Soc. 1963, 85, 337-343.

[7] White, E. H.; Rapaport, E.; Seliger, H. H.; Hopkins, T. A. The chemi- and bioluminescence of firefly luciferin: an efficient chemical production of electronically excited states. Bioorg. Chem. 1971, 1, 92-122.

[8] Seto, S.; Ogura, K.; Nishiyama, Y. A convenient synthetic method of 2-carbamoyl-6-methoxybenzothiazole, one of intermediates for the synthesis of firefly luciferin. Bull Chem. Soc. Jpn. 1963, $36,331-333$.
[9] Toya, Y.; Takagi, M.; Nakata, H.; Suzuki, N.; Isobe, M.; Goto, T. A convenient synthetic method of 2-cyano-6-methoxybenzothiazole - a key intermediate for the synthesis of firefly luciferin. Bull Chem. Soc. Jpn. 1992, 65, 392-395.

[10] Rosenmund, K. W.; Harms, H. Das am Ringkohlenstoff gebundene Halogen und sein Ersatz durch andere Substituenten. I. Mitteilung: Ersatz des Halogens durch die Carboxylgruppe. Eur. J. Inorg. Chem. 1919, 52, 1749-1756.

[11] Sandmeyer, T. Ueber die Ersetzung der Amidgruppe durch Chlor in den aromatischen Substanzen. Eur. J. Inorg. Chem. 1884, 17, 1633-1635.

[12] Ren, Y.; Liu, Z.; Zhao, S.; Tian, X.; Wang, J.; Yin, W.; He, S. Ethylenediamine/ $\mathrm{Cu}(\mathrm{OAc})_{2} \mathrm{H}_{2} \mathrm{O}$-catalyzed cyanation of aryl halides with $\mathrm{K}_{4}\left[\mathrm{Fe}(\mathrm{CN})_{6}\right]$. Catal. Commun. 2009, 10, 768-771.

[13] Zanon, J.; Klapars, A.; Buchwald, S. L. Copper-catalyzed domino halide exchange-cyanation of aryl bromides. J. Am. Chem. Soc. 2003, 125, 2890-2891.

[14] Sundermeier, M.; Mutyala, S.; Zapf, A.; Spannenberg, A.; Beller, $M$. A convenient and efficient procedure for the palladiumcatalyzed cyanation of aryl halides using trimethylsilylcyanide. J. Organomet. Chem. 2003, 684, 50-55.

[15] Velmathi, S.; Leadbeater, N. E. Palladium-catalyzed cyanation of aryl halides using $\mathrm{K}_{4}\left[\mathrm{Fe}(\mathrm{CN})_{6}\right]$ as cyanide source, water as solvent, and microwave heating. Tetrahedron Lett. 2008, 49, 4693-4694.

[16] Grossman, O.; Gelman, D. Novel trans-spanned palladium complexes as efficient catalysts in mild and amine-free cyanation of aryl bromides under air. Org. Lett. 2006, 8, 1189-1191.

[17] Beletskaya, I. P.; Sigeev, A. S.; Peregudov, A. S.; Petrovskii, P. V. Catalytic Sandmeyer cyanation as a synthetic pathway to aryl nitriles. J. Organomet. Chem. 2004, 689, 3810-3812.

[18] Schareina, T.; Zapf, A.; Maegerlein, W.; Mueller, N.; Beller, M. Copper-catalyzed cyanation of heteroaryl bromides: a novel and versatile catalyst system inspired by nature. Synlett. 2007, 4, 0555-0558.

[19] Schareina, T.; Zapf, A.; Beller, M. An environmentally benign procedure for the Cu-catalyzed cyanation of aryl bromides. Tetrahedron Lett. 2005, 46, 2585-2588.

[20] Lang, H.; Jakob, A.; Milde, B. Copper (I) alkyne and alkynide complexes. Organometallics 2012, 31, 7661-7693.

[21] Evano, G.; Blanchard, N.; Toumi, M. Copper-mediated coupling reactions and their applications in natural products and designed biomolecules synthesis. Chem. Rev. 2008, 108, 3054-3131.

[22] Zhang, G.; Yi, H.; Zhang, G.; Deng, Y.; Bai, R.; Zhang, H.; Miller, J. T.; Kropf, A. J.; Bunel, E. E.; Lei, A. Direct observation of reduction of $\mathrm{Cu}$ (II) to $\mathrm{Cu}$ (I) by terminal alkynes. J. Am. Chem. Soc. 2014, 136, 924-926.

[23] Schareina, T.; Beller, M. Copper-Catalyzed Cyanations of Aryl Halides and Related Compounds. In Copper-Mediated CrossCoupling Reactions. Evano, G., Blanchard, N., Eds. Wiley: New Jersey, 2013; pp 313-334.

[24] Schareina, T.; Zapf, A.; Cotte, A.; Mueller, N.; Beller, M. A bioinspired copper catalyst system for practical catalytic cyanation of aryl bromides. Synthesis 2008, 20, 3351-3355.

[25] Sigeev, A.; Beletskaya, I.; Petrovskii, P.; Peregudov, A. Cu (I)/ $\mathrm{Cu}$ (II)/TMEDA, new effective available catalyst of sandmeyer reaction. Russ. J. Org. Chem. 2012, 48, 1055-1058.

[26] Becke, A. D. Density-functional exchange-energy approximation with correct asymptotic behavior. Phys. Rev. 1988, 38, 3098. 
[27] Frisch, M.; Trucks, G.; Schlegel, H.; Scuseria, G.; Robb, M.; Cheeseman, J.; Scalmani, G.; Barone, V.; Mennucci, B.; Petersson, G. Gaussian 09, Revision A. 02; Gaussian Inc.: Wallingford, CT, 2009.

[28] Dega-Szafran, Z.; Katrusiak, A.; Szafran, M. Molecular structure of the complex of $\mathrm{N}$-methylmorpholine betaine with 2,4-dinitrophenol. J. Mol. Struct. 2005, 741, 1-9.
[29] Tachikawa, M.; Mori, K.; Nakai, H.; Iguchi, K. An extension of $a b$ initio molecular orbital theory to nuclear motion. Chem. Phys. Lett. 1998, 290, 437-442.

[30] Stuckwisch, C. Derivatives of 2-amino-6-methoxybenzothiazole. J. Am. Chem. Soc. 1949, 71, 3417-3417. 